\title{
REGULAMIN PRZYZNAWANIA NAGRODY NAUKOWEJ CZŁONKA HONOROWEGO PTN
}

1. Członkiem Honorowym Towarzystwa może zostać obywatel polski lub innego kraju w uznaniu jego zasług dla neurologii lub dla Towarzystwa. Godność członka honorowego nadaje Walne Zgromadzenie Delegatów na wniosek Zarządu Głównego.

2. Członek Honorowy obywatelstwa polskiego posiada wszystkie prawa członka zwyczajnego, członek honorowy niebędacy obywatelem polskim nie posiada czynnego i biernego prawa wyborczego.

3. Członek Honorowy nie opłaca składek członkowskich.

1. Prawo zgłaszania kandydatur na Członków Honorowych maja: członkowie Zarządu Głównego, Głównej Komisji Rewizyinej i Sądu Koleżeńskiego, Zarządy Oddziałów Terenowych oraz Kierownicy Klinik Neurologicznych.

2. Zarząd Główny PTN rok przed planowanym terminem kolejnego Zjazdu lub Konferencji Naukowo-Szkoleniowej wysyła informacje do Zarządów Oddziałów Terenowych i do Kierowników Klinik Neurologii o możliwości zgłaszania kandydatur na Członków Honorowych PTN.

3. Kandydatury powinny być zgłaszane na piśmie w terminie do 31 słycznia w roku, w którym odbywa się Zjazd lub Konferencja Naukowo-Szkoleniowa, z podaniem danych personalnych i zawodowych kandydata oraz omówieniem okoliczności uzasadniajacych nadanie godności Członka Honorowego.

4. Przewodniczący Zarządu Głównego przedstawia wszystkie zgłoszone kandydatury i po przeprowadzonej dyskusji zarządza tajne głosowanie Zarządu Głównego nad przyięciem kandydatur.

5. Zarząd Główny przedstawia Walnemu Zgromadzeniu tylko dwóch kandydatów z Polski i jednego z zagranicy na Członków Honorowych PTN, kłórzy uzyskali więcej niż połowę ważnych głosów na prawomocnym posiedzeniu ZG.

6. Godność Członka Honorowego Polskiego Towarzystwa Neurologicznego uzyskuja tylko kandydaci, kłórzy uzyskują w głosowaniu tajnym ponad 50 procent głosów delegatów obecnych na prawomocnym WZD. 